Crisis of the "Nehruvian Consensus" or Pluralization of Indian Politics? Aligarh Muslim University and the Demand for Minority Status

\title{
Laurence Gautier
}

\section{CpenEdition}

\section{Journals}

Electronic version

URL: http://journals.openedition.org/samaj/6493

DOI: $10.4000 /$ samaj.6493

ISSN: 1960-6060

Publisher

Association pour la recherche sur l'Asie du Sud (ARAS)

\section{Electronic reference}

Laurence Gautier, "Crisis of the "Nehruvian Consensus" or Pluralization of Indian Politics? Aligarh Muslim University and the Demand for Minority Status ", South Asia Multidisciplinary Academic Journal [Online], 22 | 2019, Online since 01 December 2019, connection on 10 July 2020. URL : http:// journals.openedition.org/samaj/6493; DOI : https://doi.org/10.4000/samaj.6493

This text was automatically generated on 10 July 2020

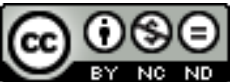

This work is licensed under a Creative Commons Attribution-NonCommercial-NoDerivatives 4.0 International License. 


\title{
Crisis of the "Nehruvian Consensus" or Pluralization of Indian Politics? Aligarh Muslim University and the Demand for Minority Status
}

\author{
Laurence Gautier
}

1 Away from Aligarh's bustling old city, across the railway track which divides the city into "two adjacent towns" (Mann 1992:28), lies the sprawling campus of Aligarh Muslim University (AMU). Bab-e-Syed, a grand gate made of sandstone and marble, acts as the visible frontier between the outside world and the venerable institution. Inside, the sherwanis that some students wear and the cusped arches and domes of older buildings give the campus a distinct mahaul (atmosphere) that further marks it out from the rest of the city.

2 Although AMU occupies a separate, somehow peripheral space in Aligarh city, it remains for many a central symbol of Muslims' tahzeeb (culture) and socio-political status in India. From the very outset, Aligarh's founders projected their college-then known as the Muhammedan Anglo-Oriental College-as an all-India Muslim institution. Sir Syed ${ }^{1}$ and his colleagues claimed to serve the interests of all Indian Muslims, even though in practice they mostly addressed North Indian ashraf ${ }^{2}$ elites. After independence, many Aligarhians continued to see their alma mater as a source of pride for the community. To them, it epitomized Sir Syed's efforts to uplift Muslims and to preserve the legacy of the glorious Mughal past. By contrast, many outsiders regarded the institution with suspicion. Due to students and teachers' widespread support to Muslim League in the 1940s, AMU became a lieu de mémoire (memorial site) of partition and a symbol of so-called Muslim separatism (Brass 200. In either case, AMU was more than an educational institution. To its supporters and detractors alike, it appeared as a symbol of Muslims' position in India before and after independence.

3 AMU therefore occupies a very special position in the Indian public sphere. It is simultaneously a central university, under control of the central government, and the 
Muslim institution par excellence, supposed to serve and represent the Muslim community. As such, it draws the attention of a wide range of actors, much beyond the campus's premises-government, politicians and religious organizations-for whom AMU constitutes a privileged platform to address the community. At the same time, AMU is no mere symbol to be easily appropriated by outsiders. As a university, it is a place of vibrant debates among students, teachers and administrators, who need not share the same vision of the University's role and character.

In this article, I explore the dual nature of AMU as a Muslim symbol and as a site of contentious politics. I focus in particular on the campaign for AMU's minority status (1965-1981) and its impact on Indian politics in the post-Nehruvian period. What started in 1965 as an internal university dispute soon transformed into a central Muslim issue. The campaign revived AMU's role as a key site of Indian Muslim politics, as the minority status question crystallized mounting resentment against the government and provided a common platform to heterogeneous forces-students, teachers, as well as Muslim organizations-who all claimed to serve Muslim interests.

5 Historian Mushirul Hasan regards the campaign for Aligarh's minority status as a symptom of the "sectarian passions" which eroded, from the 1960s onwards, the Nehruvian "consensus" based on the idea of a secular, composite and democratic India (1997:258-61, 276). Like him, other scholars interpret the post-Nehruvian period as one of "crisis," epitomized by the Emergency, the rise of communal violence and finally the coming to power of the Hindu right in the 1990s. Sunil Khilnani, for instance, contrasts Nehru's supposed achievements-the establishment of a strong state and a stable social order-with the rise of political competition and the emergence of group-based demands in the latter period. He argues that this political competition encouraged politicians to resort, increasingly, to identity politics in order to mobilize their electorates. For him, this process of identity creation was dangerous as it often led to conflict rather than competition, thereby corrupting democratic principles (Khilnani 1997).

6 Yet one need not interpret the emergence of new political formations representing group-based interests simply as a source of sectarianism. Jaffrelot (2003) has argued persuasively that the political mobilization of the lower castes from the 1960s onwards marked the beginning of a "silent revolution," which allowed the progressive transfer of power from a small upper-caste minority to much larger subaltern groups. Just as revisionist historians have emphasized the contingent character of partition thereby challenging a teleological interpretation of the late colonial period through partition's lens, it seems important to stop reading the post-Nehruvian period merely as a period of crisis, or as part of a sequence, leading inevitably to the explosion of communal violence and to the rise of Hindutva in the 1990s (Jalal 1994). Instead, one might read it as a period of pluralization of Indian political life, marked by the formation of political groups defending group-based interests.

7 With this goal in mind, in this article I highlight the role of university politics, particularly at AMU, in the emergence of contentious voices challenging the so-called "Nehruvian consensus" from the 1960s onwards. I argue that the Aligarh campaign played a key role in re-shaping the contours of Muslim politics after independence; it contributed to the re-emergence of the demand for Muslim minority rights, largely delegitimized after partition; it provided a platform for an increasingly assertive Muslim leadership which claimed to represent the so-called "Muslim community"; it 
constituted a laboratory for issue-based coalitions, which, in the absence of a strong Muslim political party, became a dominant feature of Muslim politics, especially in North India. By putting forward the demand for minority status, ${ }^{3}$ the Aligarh campaign challenged Congress's "hegemonic" discourse on secular nationalism (Bajpai 2011:168). As such, it participated in the larger pluralization of Indian politics in the 1960s, marked by the erosion of Congress's dominance, much before the post-Emergency crisis. ${ }^{4}$

\section{From a University Controversy to a Muslim Issue}

How did the question of AMU's minority status first arise? In Muslim Political Discourse in Postcolonial India, Hilal Ahmed (2014) insists on the fact that there is no monolithic Muslim politics, nor set packages of Muslim issues. He shows how specific objects-in his case, Indo-Islamic monuments-can be transformed into Muslim issues and appropriated to justify the existence of a single Muslim community. In a similar way, in the first part of this article, I will show how a university matter-a controversy over quotas for internal students-became a Muslim minority issue.

After partition, Nehru and his Education Minister, Maulana Azad, decided to grant AMU the central university status. I have argued elsewhere that this decision reflected Nehru and Azad's efforts to transform the erstwhile "arsenal of Muslim India"

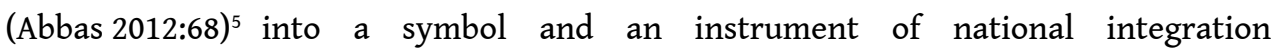
(Gautier 2016). Despite AMU's association with the Muslim League in the 1940s, after partition, Nehru and Azad did not seek to punish the institution. Instead, they aimed to clear its Muslim League legacy so that it could become a national institution. To fulfil this objective, Nehru and Azad appointed Zakir Husain, known for his commitment to Congress's one-nation policy, at the head of the institution. In Husain's words, Aligarh's new objective was to "revive hope and faith" among the "despondent Muslim masses scattered all over the country." (NAI, ME, File 41-90/50-D.3, 1950). By transforming AMU into a national institution, symbolic of composite India, Nehru, Azad and Husain hoped to rally Muslim citizens battered by partition to "an integrated nationhood in a secular democratic state" (NAI, ME, 41-90/50-D.3, 1950).

Large sections of the student and teacher body supported this national re-orientation, especially those associated with the Left. Others, however, feared that such reforms, combined with government interference, would erode Aligarh's Muslim character. This was the case of Hameed-ud-Din Khan ([1966]2006), a professor of Persian, who argued that a "considerable number" of progressives had been "imported" from other universities "as an antidote to any lingering Muslim League infection" in AMU's body (p. 92). Khan added: "Some non-Muslims of known anti-Muslim bias were also brought in and installed as Heads of Departments" (p.93). To him, this recruitment policy reflected the government's attempts to carry out the shuddhi (Hindu purification) of the institution, therefore threatening the Muslim character of the University.

The majoritarian policies of the Uttar Pradesh (UP) government heightened these apprehensions. Their imposition of Hindi as the sole official state language and their efforts to reform the Muslim Personal Law appeared to many UP Muslims as an attempt to impose a uniform Hindu culture (Hasan 1997; Brass 1974). These anti-Muslim moves contributed to a volatile atmosphere on campus. In 1961, a dispute between Hindu and Muslim students sparked the worst communal riots in Aligarh since Independence. 
State authorities quickly laid the blame on AMU students, ignoring the role played by the RSS and the Jana Sangh (Brass 2011:176-80; Pandit 2014:110-22). The government's biased reaction reinforced among large sections of Aligarh's Muslim population the feeling that state authorities were either unable or unwilling to protect them and to treat them fairly.

In response, many Muslim residents chose to vote during the 1962 elections for the Dalit-based Republican Party of India, instead of Congress. AMU faculty played a decisive role in this Dalit-Muslim alliance. Abdul Bashir Khan, AMU's Proctor, and Ravind Khwaja, who taught medicine at the University, joined hands with B.P. Maurya, the local leader of the Republican Party of India (RPI), ${ }^{6}$ himself a Law professor at AMU, to beat Congress in the Assembly and Lok Sabha elections (Jaffrelot 2003:106-07; Duncan 1979:275-93). Although this Dalit-Muslim alliance did not last long, it had an enduring impact. First, it put an end to Congress's power in Aligarh's district. Second, it showed that Congress could no longer take Muslim voters for granted. If neglected, they could ally with another minority-in this case the Scheduled Castes-to challenge the party's dominance, thereby opening the way to a pluralization of political forces in the former Congress "heartland" (Kudaisya 2006).

13 It is in this climate of mounting tensions between Congress and UP Muslims, palpable at AMU, that the question of Aligarh's minority status arose. What was to become a major Muslim issue first started as an internal controversy over a university matterstudent quotas. This controversy reflected internal debates over AMU's Muslim character as well as students' concerns over their professional future. Indeed, for many University members, the composition of AMU's student population constituted a more essential element of Aligarh's Muslim character than its curriculum. These students and teachers considered that AMU's resources should remain in the hands of Muslims and should primarily benefit Muslim students (AMU 1961:116, 139).

This concern over access to AMU's resources became particularly acute at a time when the high levels of graduate unemployment generated widespread anxiety among students. Graduate unemployment had been a long-standing problem, which was not restricted to Muslim students. Already in 1935, the Sapru Committee had expressed concerns about the "alarming" extent of unemployment among University graduates (India 1944:28). In 1966, once again, the Kothari Commission stressed the "large rate of under-employment or unemployment, particularly among the educated" (India 1966:2).

In some ways, thus, the situation of students at Aligarh was comparable to that of students in other universities. Yet, at AMU, it crystallized among students a strong sense of being discriminated against as Muslims. Badruddin Tyabji (1994), AMU's ViceChancellor in the early 1960s, himself believed that there was a "prejudice that prevailed in employment circles against students who had passed out from Aligarh," a prejudice derived, he argued, from AMU's reputation "as a hotbed of Muslim reaction...more or less linked with Pakistan" (p.146). To address students' apprehensions, he proposed to raise the proportion of internal students ${ }^{7}$ from $50 \%$ to $75 \%$ in the Engineering and Medical Colleges, two of the most sought-after departments at AMU where about half of the students were non-Muslims (Tyabji 1958:3). Given the fact that most of AMU's internal students were Muslim, this measure would help secure a higher proportion of Muslim students in these departments without resorting to religion-based quotas ${ }^{8}$ deemed more controversial. ${ }^{9}$ Through this measure, Tyabji (1994) thus hoped to address two problems at once: to provide his students with 
promising job prospects and to reassure those who feared that AMU may lose its Muslim character (pp.165-6).

Unsurprisingly, the decision of his successor, Ali Yavar Jung, to bring internal quotas back to $50 \%$ had exactly the opposite effect. The announcement of this decision in April 1965 sparked a series of protests, one of which degenerated into a violent attack against the Vice-Chancellor. Violent protests were not completely unusual in Indian universities. ${ }^{10}$ State administrators usually interpreted them as symptoms of students' indiscipline (India 1960; Kabir 1955). Yet, in AMU's case, the Education Minister M.C. Chagla, quickly lent an ideological dimension to the incident. He projected students' agitation as a battle between communal and secular forces (NMML, 80, 1965). ${ }^{11} \mathrm{~A}$ few days after the attack, he demanded the closure of the University and the adoption of an ordinance which reinforced the control of the government over the institution. According to him, these "drastic measures" were required to "eliminate a small, fanatic, obscurantist and reactionary section in the University" who threatened the national and secular character of the institution (Chagla 1974:380). Chagla's drastic measures, far from settling the issue, sparked a new series of protests inside the University. The government deployed the police on campus and several students and members of the administrative bodies, said to have encouraged the agitation, were arrested..$^{12}$ In response, members of the Students' Union formed an Action Committee to lead the protests against quota reforms and against the government's ordinance (NMML, 90, 1965). ${ }^{13}$

17 This campaign, which now involved students as well as teachers and staff members, revived earlier political and factional divisions between "reformists," who, like the Vice-Chancellor, supported the re-orientation of the University, and "conservatives," keen to preserve AMU's Muslim character. Thus, while Jung (1983) warned his colleagues against the "creation of citadels or pockets of communal exclusivism" (pp. 229-30). ${ }^{14}$ The Pro-Vice-Chancellor argued that Aligarh's mission was primarily to train Muslim students in accordance to "Islamic culture" (Islami tahzeeb) and "traditions" (Islami rivayat) (Khan 1969:459-60). As a result, the agitation against the reform of internal quotas-which was primarily a student issue-soon transformed into a battle over the character of the University. For rival factions inside the institution, it became a fight either between secular and communal forces, or between supporters and opponents of Aligarh's Muslim character.

18 The university agitation reached a new dimension when Muslim organizations joined the protestors' ranks. The agitation started barely one year after the establishment of Majlis-e-Mushawarat, a new coalition of Muslim religious and political organizations which aimed to represent Muslim interests at pan-Indian level. The formation of this association represented a significant shift in Muslim politics. After partition, large numbers of Muslims preferred to contain the markers of their difference to avoid further stigmatization and violence (Sherman 2015). In UP, leaders of the Muslim League, deemed responsible for Muslim separatism, decided to dissolve their organization, thereby "dismantling the former Muslim heartland" (Kudaisya 2006:35966). Meanwhile, Congress Muslim leaders, particularly Maulana Azad, urged Indian Muslims to turn away from communal organizations to join Congress.

19 It is only in the early 1960s that some Muslim groups or individuals began to set up distinct platforms to represent Muslim interests. These initiatives responded in large measure to the resurgence of communal violence in different parts of India. In 
February 1961, the eruption of communal riots in Jabalpur marked a turning point after a decade of relative calm (Graff and Galonnier 2013:10). Syed Mahmud ([1964] 1974), long-serving secretary of the Congress party and a close friend of Nehru, called an allIndia Muslim convention to urge the government to implement a "just" political system that would acknowledge the "rightful" position of Muslim citizens (Pp. 326-9). ${ }^{15}$ Three years later, after a new wave of communal riots, Muslim organizations with widely divergent views came together to establish the Majlis-e-Mushawarat.

The formation of this body marked a rapprochement between Jamiat Ulama, Congress's ally, ${ }^{16}$ with its former arch-rival, the Muslim League. It also allowed Jamaat-e-Islami, ${ }^{17}$ until then a marginal organization opposed to secular democratic principles, to gain greater visibility and legitimacy thanks to their alliance with more mainstream bodies (Quraishi 1971; Ahmad 2010:198-200). Together, these otherwise very different groups aimed to form a common platform able to defend Muslim interests, thus pointing to government's failure, or even unwillingness, to protect its Muslim citizens.

Majlis leaders soon joined the Aligarh agitation. They transformed the university issue into a Muslim issue, of relevance to all Muslim citizens, much beyond the campus premises. In July 1965, they organized a day of prayer to advertize their position on AMU. A resolution was read out in mosques all over North India. Majlis urged their audience to send telegrams to the President, the Prime Minister and the Home Minister in order to press their demand for the withdrawal of the government's ordinance (NMML, 81, 1965). ${ }^{18}$ Around the same time, they organized, along with Aligarh's "Old Boys" (alumni), a well-publicized convention in Lucknow to protest against the government's ordinance (NMML, 90 and 81, 1965). ${ }^{19}$ These events met with a widespread echo in the Hindi, English and Urdu press, in UP as well as in other parts of India. Newspapers based not only in Delhi, Lucknow and Patna, but also in Calcutta, Kerala, Hyderabad and Bombay, published reports on Majlis's meetings and on the AMU Action Committee. ${ }^{20}$ The campaign thus revived AMU's value as a Muslim symbol, anchored in UP, yet resonating in other parts of India. As such, it provided Majlis leaders with a privileged platform to project themselves as all-India Muslim leaders.

While the students' agitation had started as a purely internal controversy over the reduction of internal quotas, Majlis members gave a new orientation to the Aligarh campaign. At the Lucknow Convention of August 1965, they argued that the control of Aligarh's administration should rest exclusively in Muslim hands. To justify this, they invoked the constitutional right of religious minorities to "establish and administer the educational institutions of their choice" (NMML, 90, 1965). ${ }^{21}$ Here, then, was the demand for minority status articulated clearly for the first time. Beyond students' demand to secure a high proportion of seats for Muslim students, Majlis members aimed to secure, through this minority status, an overall Muslim control of the institution.

This invocation of Muslims' minority rights represented a significant breach in Congress's "hegemonic" discourse on secular nationalism. After partition, this discourse, which prioritized national unity, had largely delegitimized religious groups' minority demands, cast as communal. This can explain why in the 1950s large-scale campaigns for the recognition of Urdu were framed in terms of linguistic minority rights, not in terms of Muslim rights (Brass 1974). By contrast, in 1965, Majlis's convention clearly projected the demand for AMU's minority status as a Muslim demand. In so doing, Majlis's leaders distanced themselves from the dominant rhetoric 
on national unity to project Muslims as a minority group, in need of special rights and protection.

Majlis further insisted on the religious character of AMU, an element which was absent from students' earlier demands. In June 1965, they adopted a resolution which stated that "special facilities should be continued for the religio-moral instruction of students, as well as for the teaching of theology, Islamic Studies, Arabic, Persian and Urdu." They added: "special facilities should be provided for the performance of religious duties" and the University "should be saved from the anti-God elements which are today dominating its affairs" (Wright 1966a). ${ }^{22}$ These demands and formulations reflected Jamaat-e-Islami's powerful influence inside Majlis-e-Mushawarat (NMML, 90, 1965). ${ }^{23}$ For Jamaat members, the main objective was not simply to gain greater control over the institution. They aimed to transform the University, earlier denounced as a "slaughter-house" (Ahmad 2010:124-5), into an institution faithful to their conception of Islam. The AMU campaign thus provided them with an opportunity to advance their own conception of Muslim identity, framed primarily in religious terms, as well as their own conception of AMU's Muslim character, defined in a combative fashion so as to exclude "anti-God" elements from the Muslim institution.

Jamaat-e-Islami's forceful intervention in the Aligarh campaign prompted Jamiat Ulama, Congress's long-term ally, often considered as Muslims' main representative body after partition, to play a more assertive stance vis-à-vis the government. In June 1965, soon after the beginning of the Aligarh agitation, the organization filed a case against the government's ordinance. The Jamaat-led Majlis denounced this independent initiative. In response, Jamiat Ulama accused its "enviers," i.e. the Jamaat, of sowing division among Muslims. According to a pamphlet published by Jamiat Ulama: "The enviers (haasiden) of the Jamiat Ulema and the divisive elements (tafriqa anasir) will try to ignite (bhadkana) [fears among] innocent-minded (sadah loh) Muslims" and "spread anxiety" (bad dili phelana) while speaking in the name of "the unity of the millat" (community) (Qasmi 1965:14).

Jamiat Ulama members projected themselves as the sole true representatives of Muslim interests, "[leading] alone the battle to protect the fundamental rights (bunyadi huquq) of Muslims in India after the revolution (inqilab) of 1947 and [putting] their lives at stake to protect Muslims from the catastrophic (qayamat khaiz) effects of partition" (Qasmi 1965:4). Paradoxically, these bitter rivalries reinforced the notion of an all-India Muslim community. Even as they attacked each other, Jamaat-e-Islami and Jamiat Ulema members did so to claim leadership over a single Muslim community. Through their competing publications, pamphlets and speeches, they gave wider currency to the notion of an all-India Muslim community, with shared rights and interests.

The Aligarh campaign therefore crystallized the rise of a Muslim politics centered around the defense of minority rights, which had been largely delegitimized after partition. It encouraged the emergence of a more assertive Muslim leadership at a time when Muslim organizations sought to establish a structure independent of government to represent the interests of the community. Despite a few dissonant voices within the University (NMML, 90, 1965), ${ }^{24}$ the campaign garnered widespread support within and outside campus. In fact, it seems that the government's repeated refusals to grant Aligarh minority status added momentum to the campaign. The failure of the new AMU Act (1972) to recognize AMU's minority status thus sparked a new upsurge of students' mobilization in 1972-1973..$^{25}$ Again, from 1977 to 1981, Janata's and then Congress's 
constantly delayed promises to grant AMU the minority status kept students and other campaigners on tenterhooks. ${ }^{26}$ For many Muslims, Aligarh had become the symbol of their fight against state discrimination and for the recognition of their rights as a minority.

The demand for Aligarh's minority status directly challenged Congress's discourse on secular nationalism, which prioritized national unity over group rights. As Partha Chatterjee and Aditya Nigam have suggested, the secular nationalist discourse remained dominant until the 1980s in civil society, i.e. in the sphere of modern civil institutions, but it did not have the same hegemonic position in political society, i.e. in the "domain of daily negotiations" between the population and the state, ${ }^{27}$ even before the Emergency. At AMU, the actors of the minority status campaign found in the language of minority rights the legitimizing framework to express their grievances, demand access to educational resources and seek protection from an unreliable state, deeply suspect of majoritarianism. In so doing, they contributed to reinforcing the idea that Muslim citizens were minority citizens, whose rights and interests were mediated by their belonging to a single Muslim community.

\section{The Role of Student Politics in the Pluralization of Indian Politics}

29 This reconfiguration of Muslim politics, visible at AMU, should be seen as part of a larger pluralization of Indian politics in the post-Nehruvian era. What characterized this period, beside the rise of oppositional parties, was the emergence of non-party actors, who played an important part in the erosion of the so-called "Nehruvian consensus." As sites of "contentious politics" (Tilly and Tarrow 2015), universities like AMU participated in this evolution: they facilitated the emergence of counternarratives as well as alternative sources of representation. At AMU, the campaign for Aligarh's minority status crystallized the rise of the minority rights counter-narrative. But in the absence of a strong Muslim political party, it also served as a laboratory for alternative forms of mobilization-student politics and issue-based coalitions.

First, the campaign allowed AMU students to emerge as a significant political force within and beyond the premises of the University campus. AMU students embraced vigorously the idea that they had a special responsibility in the defense of Muslims' rights and interests. As members of this iconic institution, Aligarh students were, according to former Aligarh Muslim University Students' Union President (AMUSU) Ali Amir, "answerable for their thoughts and actions in front of the whole millat and in front of the whole world" (AMUSU 1982:3-4).

31 During the campaign, students established enduring, if sometimes tense, connections with Muslim organizations and political parties. One former student, Iftikhar Alam Khan, recalls that the building of the Old Boys' Association ${ }^{28}$ on campus served as a meeting point between students and other members of the Action Committee. The old Boys' Association organized meetings for the defense of AMU status to which they invited students as well as campaigners from outside the University (I. A. Khan personal communication, March 18, 2015).

Relations based on mutual help sometimes flourished with specific Muslim leaders. Ali Amir thus recalls that: 
Faridi sahab [Dr. A.J. Faridi, leader of the Muslim Majlis in UP] was supported by the Students' Union leaders... [They] went to his constituencies. [They] provided support to his candidates, all of them. In return, he argued, "[they] only had one demand for him - the support with the minority character movement" (A. Amir, personal communication. March 13, 2014).

Akhtarul Wasey, another student leader, further speaks of a "joint venture" between students and other supporters of the minority status:

The Students' Union, the Students' Action Committee, and Old Boys... at that time there was no difference, almost all differences were melted down...All Muslim groups and anti-Congress groups were supporting [students] (Wasey, personal communication, November 7, 2013).

Arif Mohammad Khan, who presided over the Students' Union in 1973-1974, presents a slightly different picture, underlining a degree of distance between students and Muslim outfits. He recalls that "the Action Committee was there but since it was packed with Muslim political outfits...[he] kept a distance from Muslim organizations" (A. M. Khan, personal communication, March 21, 2015). Similarly, at the end of the minority status campaign in 1982, the out-going president of the Students' Union, Shakeel Ahmed Tamanna, urged his fellow students to stay away from the "net of external and internal politicians" (beruni aur andruni siasatdanon ke jaal) whose "limited objective" (mahdud maqsad) was to "exploit" students (AMUSU 1982:5). However, the very fact that he had to warn his fellow students against the politicians' "exploitation" of students suggests that such connections did or could exist between students and politicians.

The Aligarh campaign allowed certain student leaders active in the protest movement to acquire significant political capital outside University circles. Their status as AMU student leaders made them enviable allies for Muslim religious and political organizations. Despite his own reluctance towards "Muslim outfits," Arif Mohammad Khan recalls that these groups repeatedly tried to reach out to him while he was at the head of the Students' Union. According to him, "they were very keen that [he] join them." He adds: "why they needed me? ...Because that helped them if I come there as President of the Students' Union, that helped them with the Muslim masses, and that was their constituency" (A. M. Khan, personal communication, March 21, 2015).

This capacity to mobilize within and beyond the University could attract the attention of non-Muslim organizations too. In 1974, Jayaprakash Narayan asked Arif Mohammad Khan to join the Central Coordination Committee of his movement as one of its two student representatives. Khan then joined Congress after the Emergency, won a parliamentary election in Kanpur in 1980 and later occupied ministerial positions under Congress and Janata governments, becoming Union Cabinet Minister for Energy in 1989. At the time of the discussions on the new AMU bill (1980-81), he acted as an unofficial intermediary between University members and government authorities to help find a compromise between both parties (A. M. Khan, personal communication, March 21, 2015). Even if his links with the student leadership may have later weakened, ${ }^{29}$ the fact that he had once led AMU's Students' Union provided him with privileged access to a larger political platform.

Another student leader to emerge during the Aligarh campaign was Javed Habib, who became President of the Students' Union in 1978, at a time when the Janata Party had just come to power. As president, he organized several demonstrations in Aligarh and 
in New Delhi to put pressure on the new government to adopt a new AMU bill (Times of India 1978b). Habib remained deeply involved in the affairs of the University even after he withdrew from the Students' Union. He continued to intervene in public affairs, notably after the Aligarh riots in 1980 (Times of India 1980), and acted as an intermediary between students and Muslim organizations such as the Majlis-eMushawarat (Srivastava 1981). Unlike Arif Mohammad Khan, he never joined a formal political party. Like Khan, though, he used his past experience and connections as a student leader to continue to play an active role in Muslim politics. In the late 1980s, for instance, he became a leading spokesman of the All India Babri Masjid Action Committee, established in 1988 to protect the religious status of the disputed mosque (Ansari 2012).

These student activists emerged around the time of Emergency, when students played a major part in the agitations against the Congress government. Indeed, many student leaders who participated in the anti-Emergency movement went on to become senior political figures, either in the BJP (e.g. Vijay Goel, Arun Jaitley, Sushma Swaraj) or in left-wing opposition parties (e.g. Sitaram Yechury, CPI(M)) (Clibbens 2014:301). This intensification of student politics in the 1970s was part of a wider phenomenon which went beyond the scope of the Emergency. We can think of the role of student politics in the emergence of feminist groups such as the Progressive Organization of Women in Hyderabad or of Marxist influences in universities like JNU from the 1960s onwards (Kumar 1999; Lalita 2008; Batabyal 2014). At AMU, few students took direct part in the anti-Emergency movement. Yet, as mentioned above, the years just before (1972-1974) and after the Emergency (1977-1981) corresponded to some of the most intense phases of student mobilization in favor of minority status.

As the case of AMU suggests, the intensification of student politics did not necessarily depend on the spread of radical ideas but rather on the pluralization of Indian politics. This pluralization contributed to the development of universities as political sites, and vice versa. On the one hand, the burgeoning discontent against the ruling Congress was a powerful driver behind student mobilization. Ali Amir thus recalls that "antiCongress opposition always took place in Students' Union', even more so after the Emergency" (A. Amir, personal communication, March 13, 2014)..$^{30}$ On the other hand, increasing political competition encouraged parties and political leaders to turn towards students for support. ${ }^{31}$ This was the case, for instance, when Jayaprakash Narayan recruited Arif Mohammad Khan as a student representative for his movement, and also when members of the AMU Action Committee encouraged student leaders to join forces with them in the campaign for the minority status.

38 As a result of these increased connections between students and political, social and religious organizations, AMU student politics acquired a greater significance outside the campus premises. Thanks to their capacity to mobilize during the Aligarh campaign, AMU student leaders emerged as potential interlocutors for Muslim organizations as well as government authorities.

\section{The Emergence of Issue-based Coalitions}

Beyond the student body, the demand for Aligarh's minority status served as a rallying cry for individuals and organizations representing a variety of religious or political positions. As such, the Aligarh campaign epitomized the emergence of a new form of 
Muslim politics, structured around issue-based coalitions, such as the AMU Action Committee or the Majlis-e-Mushawarat. Even as Muslim citizens continued to vote for parties which did not have a specific Muslim character, the growing distrust of large sections of the Muslim population towards Congress opened up a space for this form of Muslim politics to develop outside party structures.

What characterized these issue-based platforms? A loose network of individuals and heterogeneous groups which were not continuously active, but could be re-activated for campaigns on specific issues. This was the case of Majlis-e-Mushawarat, which sprung into existence as a collective response to communal riots in the 1960s and gained momentum thanks to the Aligarh campaign. Similarly, the AMU Action Committee, started as a student body and then quickly expanded to include alumni as well as politicians and members of Muslim organizations of different shades and hues. After the decline of Majlis-e-Mushawarat, this loose coalition acted as the main coordinating body for the AMU campaign. In March 1973, its members organized a large-scale convention with no less than 600 delegates to demand "radical changes" in the AMU Act. The Committee gathered behind it an eclectic group, ranging from jurists, like Basheer Ahmed Sayeed, former member of AMU's Court and Madras High Court Judge, to religious leaders, like Abul Hasan Ali Nadwi (Ali Miyan), the reputed head of Nadwatul Ulama, and seasoned politicians: it was none other than Sheikh Abdullah, the former Prime Minister of Jammu and Kashmir, who inaugurated the 1973 convention (Sayeed 1983:90). Again, in 1978, the Action Committee brought together an impressive number of religious and political figures along with student representatives: in addition to the individuals mentioned in the table below, "other dignitaries from UP, Bihar, West Bengal, Delhi, Maharashtra, Andhra Pradesh, Madhya Pradesh and other states" also participated in the meeting (Radiance 1979). The demand for minority status provided these actors, from widely divergent political and ideological backgrounds, with a common objective. By coordinating the actions of different religious and political organizations, the Action Committee thus provided structure to a movement supposed to represent a cohesive community.

Table 1: List of dignitaries who took part in the AMU Action Committee Meet (April 22, 1978, Delhi) (Source: Radiance 1979).

\begin{tabular}{|l|l|}
\hline Name & Title \\
\hline Mufti Atiqur Rahman & President, Muslim Majlis-e-Mushawarat \\
\hline Mohammad Zulfiqarullah & President, Muslim Majlis; Union Minister of State for Finance \\
\hline Mohammad Masood Khan & Minister for Housing and Rehabilitation, U.P. \\
\hline Sulaiman Sikander & Vice-President, Majlis-e-Tameer-e-Millat \\
\hline Manzoor Alam & President, Muslim League, Rajasthan \\
\hline Iqbal Hussain Khan & President, Muslim Majlis, U.P. \\
\hline Abdul Azeem Khan & Representative, Jamaat-e-Islami Hind \\
\hline S.M. Arif & Honorary Secretary, AMU Students' Union \\
\hline
\end{tabular}


41 In the subsequent decades, similar issue-based platforms emerged, following in the footsteps of Majlis and the Action Committee. One can think of the All India Muslim Personal Law Board and the Babri Masjid Action Committee (1986) (AIMPLB 1972) ${ }^{32}$. These platforms, old and new, built upon overlapping networks of individuals and organizations. For instance, in the 1960s, Mufti Atiqur Rahman, one of Majlis's leading figures and an important actor of the Action Committee, was simultaneously associated with Jamiat Ulama and AMU's Court as well as with two of the most famous Islamic educational institutions in India, Deoband and Nadwatul Ulama. Similarly, in the 1970s and 1980s, many individuals who became pivotal figures of the AIMPLB had earlier played a leading role in Majlis-e-Mushawarat and in the Aligarh campaign. This was the case, once again, of Mufti Atiqur Rahman, as well as Syed Abul Hasan Ali Nadwi, the head of Nadwatul Ulama. Network-oriented studies of social movements have shown that social movements not only draw strength from existing networks, they also produce new ties of solidarity, which can then come into use for subsequent mobilizations (Diani 1997). In much the same way, the ties that Majlis-e-Mushawarat and the AMU Action Committee had created in the 1960s facilitated the formation of new issue-based platforms which, like them, took up the mission of representing Muslim interests.

Issue-based coalitions thus became a prominent feature of Muslim politics in the postNehruvian period, especially in North India, where Majlis, AIMPLB and of course the AMU Action Committee all started. They offered Muslims a model of mobilization outside party structures. In a context where large sections of the Muslim population expressed growing distrust towards Congress, these coalitions allowed heterogeneous Muslim groups to stand together outside the governing party to demand recognition for religious minority rights. At the same time, they presented an alternative to the formation of a Muslim political party. Unlike in South India, where parties such as the Indian Union Muslim League and the MIM appeared to be legitimate political actors, ${ }^{33}$ in North India, the former heartland of Muslim League, memories of partition hampered the formation of a new Muslim party (Kudaisya 2006). In this context, issuebased coalitions, which repeatedly invoked the Constitution to safeguard Muslims' minority rights, provided Muslims with another, more legitimate framework to defend their interests as a separate group. They formed part of a larger trend-the rise of nonparty actors defending group rights and interests. One can think of student, castebased or women's movements which all flourished in the post-Nehruvian period (Nigam 2006). Along with these non-party actors, Muslim coalitions put to test Congress's "hegemonic" discourse on national unity, thereby contributing to the pluralization of Indian politics.

However, the strength of issue-based coalitions, i.e. their flexible and catch-all character, was also their main weakness. These loose coalitions were often characterized by a weak ideological cohesion and marred by internal rivalries. These prevented the formation of strong ties of mutual trust and solidarity (Diani 1997), which would have allowed coalition actors to build a stable structure of Muslim representation. The fast decline of Majlis-e-Mushawarat is a good case in point: from the beginning, the rivalries between Jamaat-e-Islami and the Jamiat Ulema, visible during the Aligarh campaign, deeply affected the cohesion of the new association and its capacity to act in the name of all Indian Muslims (Quraishi 1971). 

campaign, members of Majlis-e-Mushawarat tried to take advantage of the growing competition between Congress and its rivals to press their demands for minority status. In the run-up to the 1971 elections, Majlis leader A.J. Faridi negotiated with Congress MPs the promise that AMU would become a minority institution in exchange for Muslim support. ${ }^{34}$ Meanwhile, Jamiat Ulema published pamphlets warning the government that "there will be great disappointment, frustration and dissatisfaction among the members of the minority and in the country" if the government were to ignore this demand (Madani 1972:5). Yet, Congress and later the Janata-led government repeatedly failed to keep their promise, despite the ongoing mobilization of students and Muslim organizations. It was only in 1981, after the Emergency and after the first defeat of Congress at the national level, that Parliament adopted an Act which satisfied the campaign's supporters. This long delay shows the limited capacity of Muslim organizations to exert influence over political parties, despite their pressure tactics. These coalitions further failed to build a stable Muslim constituency of their own. A.J. Faridi's attempts, in 1969, to transform Majlis's UP branch into a political party, met with limited success. Muslim Majlis won but a couple of seats in the state elections, that too on independent tickets (Khan 1980). Issue-based platforms such as Majlis or the AMU Action Committee therefore emerged as an alternative to both Congress and to Muslim party politics, but as a weak alternative, only able to mobilize punctually, on issues with a strong emotional appeal.

\section{Conclusion}

The Aligarh campaign, which took off soon after Nehru's death, played a key role in the reconfiguration of Muslim politics in the post-Nehruvian period. By bringing together a wide range of actors-students, religious organizations and Muslim politicians, in the defense of a common cause-the recognition of AMU's minority status, it crystallized the resurgence of the demand for minority rights and facilitated the formation of issuebased coalitions speaking in the name of Muslim interests.

This form of Muslim minority politics needs not be regarded primarily as a symptom of sectarian tendencies let loose by the erosion of the Nehruvian consensus. Movements such as the campaign for Aligarh's minority status arose largely as a response to Congress's failure, after independence, to ensure that Muslims would be treated as fullfledged citizens in the new nation-state. By putting emphasis on Muslims' group rights, these minority politics contributed, more largely, to the pluralization of Indian politics as they questioned, along with low-caste movements or other "infra-nationalisms," Congress's hegemonic discourse on national unity (Nigam 2006:86).

47 However, the emergence of these "little selves" could also facilitate the growth of majoritarian tendencies (Nigam 2006). Indeed, the rise of the Hindu right in the 1980s both fueled the calls for Muslims' protection and fed itself upon this type of minority politics: the increased emphasis on minority identity lent credence to their majoritarian rhetoric, which portrayed Muslims as the internal other.

This may explain why, in parallel to issue-based platforms defending minority rights, alternative voices emerged among Muslims, which either challenged or ignored this type of minority politics. One may think of radical student movements like SIMI or of the Pasmanda movement in the 1990s, which shared a deep dissatisfaction with the

South Asia Multidisciplinary Academic Journal, 22 | 2019 
established Muslim leadership, too narrowly focused on minority issues. ${ }^{35}$ Similarly, in the post-Babri Masjid period, some scholars and educationists urged their coreligionists to turn away from "emotional" issues to focus instead on education in order to address Muslims' "real" issues, i.e. socio-economic backwardness (Gautier 2016:161214).

There again, universities, especially AMU, appeared as privileged sites for the emergence of alternative strategies. SIMI first emerged at Aligarh during the Emergency as students associated with Jamaat-e-Islami aspired to emancipate themselves from their elders (Ahmad 2005:2010). In the 1990s, a few students formed the Forum for Democratic Rights with the aim of reorienting Muslims' attention towards socio-economic uplift. According to Mohammad Sajjad, a former member of this group, their objective was to promote a "new brand of Muslim politics" within a "secular democratic order" (Sajjad 2014). Meanwhile, some of AMU's key administrative figures, like Vice-Chancellor Syed Hamid, tried to revive a new Aligarh movement which would focus on backward Muslims' socio-economic uplift rather than religious and cultural issues (Gautier 2016:173-4, 207). Thus, even after the end of the campaign for the minority status, AMU remained a laboratory for diverse forms of Muslim politics, with an aim to reach out to the Muslim community, much beyond the University's premises.

\section{BIBLIOGRAPHY}

Abbas, Amber. 2012. "Narratives of Belonging Aligarh Muslim University and the Partitioning of South Asia." PhD dissertation, University of Texas, Austin.

Ahmad, Irfan. 2005. "Between Moderation and Radicalization: Transnational Interactions of Jamaat-e-Islami of India." Global Networks 5(3):279-99.

Ahmad, Irfan. 2010. Islamism and Democracy in India. The Transformation of Jamaat-e-Islami. Ranikhet: Permanent Black.

Ahmed, Hilal. 2014. Muslim Political Discourse in Postcolonial India: Monuments, Memory, Contestation. New Delhi: Routledge.

Alam, Anwar. 2003. "Democratisation of Indian Muslims. Some Reflections." Economic and Political Weekly 38(46):4881-5.

Alam, Javeed. 1993. "The Changing Grounds of Communal Mobilisation: The Majlis-i-IttehadulMuslimeen and the Muslims of Hyderabad." Pp.146-76 in Hindus and Others. The Question of Identity in India Today, edited by G. Pandey. New Delhi: Viking.

Ali, S.A. 1982. Hindustan Mein Islam ka Mustaqbil aur Muslim University. Delhi: Markazi Maktaba Islami.

Aligarh Muslim University Enquiry Committee. 1961 "Report of the Aligarh Muslim University Enquiry Committee.” Aligarh: Aligarh Muslim University. 
Aligarh Muslim University's Students' Union. 1982. Khutbat. Aligarh: Aligarh Muslim University's Students' Union.

Altbach, Peter. 1968. "Student Politics and Higher Education in India." Daedalus 97(1):254-73.

Ansari, N.A. 2012. “Obituary, Javed Habib.” Milli Gazette, December 1. Retrieved January 19, 2019 (http://www.milligazette.com/news/4622-javed-habib).

Bajpai, Rochana, 2011. Debating Difference: Group Rights and Liberal Democracy in India. New Delhi: Oxford University Press.

Batabyal, Rakesh 2014. JNU. The Making of a University. Noida: Harper Collins.

Brass, Paul. 1974. Language, Religion and Politics in North India. Cambridge: Cambridge University Press.

Brass, Paul. 2003. The Production of Hindu-Muslim Violence in Contemporary India. Seattle: University of Washington Press.

Brass, Paul. 2011. An Indian Political Life. Charan Singh and Congress Politics, 1937 to 1961. New Delhi: Sage.

Chagla, Mahomedali Currim. 1974. Roses in December. An Autobiography. Bombay: Bharatiya Vidha Bhava.

Clibbens, Patrick. 2014. “The Indian Emergency, 1975-77.” PhD dissertation, University of Cambridge.

Di Bona, Joseph 1969. "Elite and Mass in Indian Higher Education: The Case of Allahabad University." Pp. 131-71 in Turmoil and Transition: Higher Education and Student Politics in India, edited by P.G. Altbach. New York: Basic Books.

Diani, Mario. 1997. "Social Movements and Social Capital: A Network Perspective on Movement Outcomes." Mobilization: An International Quarterly 2(2):129-47.

Duncan, R. I. 1979. “Levels, the Communication of Programmes, and Sectional Strategies in Indian Politics, with Reference to the Bharatiya Kranti Dal and the Republican Party of India in Uttar Pradesh and Aligarh District (U.P.)." PhD dissertation, University of Sussex.

Engineer, Ali Asghar. 2010. "Reservation for Muslims." Economic and Political Weekly 39(36):3984-5. Gautier, Laurence 2016. "The Role of Muslim Universities in the Redefinition of Indian Muslim Identities after Partition (1947-1990s).” PhD dissertation, University of Cambridge.

Graff, Violette and Juliette Galonnier. 2013. "Hindu-Muslim Communal Riots in India I (19471986).” Violence de Masse et Résistance. Paris: Sciences Po. Retrieved January 18, 2019 (https:// www.sciencespo.fr/mass-violence-war-massacre-resistance).

Hasan, Mushirul. 1997. Legacy of a Divided Nation. Indian Muslims since Independence. London: Hurst. India. Central Advisory Board of Education. 1944. "Post-war Educational Development in India." Delhi: Central Advisory Board of Education.

India. Education Commission. 1966. "Report of the Education Commission, 1964-66: Education and National Development." Delhi: Ministry of Education.

India. University Grants Commission. 1960. "Report on the Problem of Student Indiscipline in Indian Universities.” Delhi: University Grants Commission.

Jaffrelot, Christophe. 2003. India's Silent Revolution: The Rise of the Lower Castes in North India. London: Hurst 
Jalal, Ayesha. 1994. The Sole Spokesman: Jinnah, the Muslim League and the Demand for Pakistan. Cambridge: Cambridge University Press.

Jones, Justin. 2010. “'Signs of Churning': Muslim Personal Law and Public Contestation in TwentyFirst Century India.” Modern Asian Studies 44(1):175-200.

Jung, Ali Yavar. [1965]1983. Ali Yavar Jung, a Commemoration Volume. Bombay: Popular Prakashan. Kabir, Humayun. 1955. Student Indiscipline. Delhi: Ministry of Education.

Khan, Hameed-ud-Din. [1966]2006. "Aligarh Muslim University: attitudes and trends of the MAO College and the Aligarh Muslim University since 1909. Personal observations and revelations." Sir Syed Day Magazine, pp.92-3.

Khan, Yusuf Husain. 1967. Yadon ki Duniya. Azamgarh: Dar al-musannifin.

Khan, Zafar Ali. 1980. “Majlis-e-Mushawarat.” MPhil dissertation, Aligarh Muslim University.

Khilnani, Sunil. 1997. The Idea of India. London: Penguin.

Khurshid, Salman. 2015. At Home in India, the Muslim Saga. New Delhi: Hay House.

Kudaisya, Gyanesh. 2006. Region, Nation, “Heartland”: Uttar Pradesh in India's Body Politic. London: Sage Publications.

Kumar, Radha. 1999. "From Chipko to Sati: The Contemporary Indian Women's Movement." Pp. 342-69 in Gender and Politics in India, edited by N. Menon. New Delhi: Oxford University Press.

Lalita, Ke. 2008. “Women in Revolt: A Historical Analysis of the Progressive Organization of Women in Andhra Pradesh." Pp. 32-41 in Women's Studies in India. A Reader, edited by M. John. New Delhi: Penguin Books.

Lelyveld, David. 1978. Aligarh's First Generation: Muslim Solidarity in British India. Princeton: Princeton University Press.

Madani, Asad. 1972. Rajya Sabha mein Muslim University Aligarh Tarmimi Act par Jamiatul Ulema-eHind ke Nazim 'amumi Hazrat Maulana Asad Madani MP ki Tarikhi Taqreer. New Delhi: Jamiat Ulema.

Mahmud, Syed. 1974. A Nationalist Muslim and Indian Politics. Being the Selected Correspondence of the late Dr. Syed Mahmud edited by V. Datta and B.E. Cleghorn. Delhi: Macmillan.

Mann, Elizabeth. 1992. Boundaries and Identities: Muslims, Work and Status in Aligarh. New Delhi: Sage Publications.

National Archives of India, Ministry of Education, 1950. File: 41-90/50-D.3. Letter from Zakir Husain to Rajendra Prasad, July 19, 1950.

Nehru Memorial Museum and Library, M. C. Chagla Papers. Files 80, 81 and 90.

Nigam, Aditya. 2006. The Insurrection of Little Selves. The Crisis of Secular-Nationalism in India. New Delhi: Oxford University Press.

Noorani, Abdul Ghafoor. 2003. The Muslims of India. A Documentary Record. Delhi: Oxford University Press.

Pandit, Aishwarya. 2014. "From United Provinces to Uttar Pradesh. Heartland Politics 19471970." PhD dissertation, University of Cambridge.

Qasmi, Muhammad Vaheeduddin. 1965. Ordinance Muslim University Aligarh ke Khilaf Writ Petition ka Mukhtasar Tazkarah. Aligarh: Jamiat Ulema. 
Quraishi, Zaheer Masood. 1971. “Emergence and Eclipse of Muslim Majlis-e-Mushawarat.” Economic and Political Weekly 6(25):1229-34.

Radiance. 1979. “AMU Action Committee Meet.” April 29, p.22.

Saikia, Yasmin and M. Raisur Rahman. 2019. The Cambridge Companion to Sayyid Ahmad Khan. New Delhi: Cambridge University Press.

Sajjad, Mohammad. N.d. “AMU in the 1990s: Some Aspects of Student Politics - F.D.R. (1994-99).” Aligarh movement. Retrieved January 18, 2019 (http://aligarhmovement.com/forum/ AMU_in_the_1990s_Some_Aspects_of_Student_Politics_F.D.R._1994-99).

Sajjad, Mohammad. 2014. Muslim Politics in Bihar. Changing Contours. New Delhi: Routledge. Sayeed, Basheer Ahmed. 1983. My Life, a Struggle. Madras: Academy of Islamic Research. Sherman, Taylor. 2015. Muslim Belonging in Secular India. Negotiating Citizenship in Postcolonial Hyderabad. Cambridge: Cambridge University Press.

Srivastava, R. C. 1981. “Millat's Hold on AMU Strong." Times of India, August 21, p.18.

Tilly, Charles. and Sidney Tarrow. 2015. Contentious Politics. New York: Oxford University Press.

Times of India. 1973. “AMU Closure Pre-Planned, says MP.” April 13, p.9.

Times of India. 1978a. “"Back Janata' Plea by AMU Staff, Students.” November 3, p.14.

Times of India. 1978b. "Restore Nature of AMU: Sheikh." May 14, p.4.

Times of India. 1980. “AMU Students Court Arrest near PM's House.” September 23, p.7.

Tyabji, Badruddin. 1958. “Vice-Chancellor's statement.” Muslim University Gazette, August 8.

Tyabji, Badruddin. 1994. More Memoirs of an Egoist. New Delhi: Har-Anand Publications.

Wasey, Akhtarul. 1972. “Aligarh University.” Times of India, May 3, p.6.

Wright, Theodore. 1966a. "Muslim Education in India at the Crossroads: The Case of Aligarh." Pacific Affairs 39(1/2):50-63.

Wright, Theodore. 1966b. "The Muslim League in South India since Independence. A Study in Minority Group Political Strategies.” The American Political Science Review 60(3):579-99.

\section{NOTES}

1. Sayyid Ahmad Khan (1817-1898), also known as Sir Syed, was one of the most prominent Muslim modernist reformers of British India. He was a prolific scholar as well as an institutionbuilder who established a number of educational, scientific and literary institutions including, most famously, the Muhammedan Anglo-Oriental College (1877), which later became Aligarh Muslim University (1920). See Lelyveld 1978; and Saikia and Rahman 2019.

2. In South Asia, this term designates Muslim families who claimed foreign descent, whether Arab, Turkish, Persian or Afghan. These families usually benefit from a higher social status than descendants of Indian converts.

3. Article 30 of the Constitution grants religious and linguistic minorities the right to "establish and administer educational institutions of their choice." The managing bodies of minority institutions benefit from greater autonomy: they are not subjected to the same rules as other state-controlled institutions (e.g. they need not implement "backward" quotas) and they can adopt institution-specific regulations (e.g. religious instruction, minority quotas for admission). 
4. To defend these arguments, I rely on a range of sources produced by different sections of AMU: official university publications, such as the Muslim University Gazette, Vice-Chancellors' writings, as well as speeches from Students' Union representatives. I also conducted semi-structured interviews with former students, many of whom participated in student politics in the 1960s and 1970s. The private papers of Education Minister M.C. Chagla have proven to be a very rich source to explore the relations between the government and University members as well as the role of "outsiders," especially religious organizations such as Majlis-e-Mushawarat. I have also used some of these religious organizations' pamphlets as well newspaper articles in the English and Urdu press to get as comprehensive as possible a picture of the Aligarh agitation inside and outside the University.

5. This is an expression attributed to Jinnah.

6. The Republican Party of India was established in 1957, shortly after Ambedkar's death. The party bore the stamp of his influence: instead of focusing on Scheduled Castes alone, the RPI was to build alliances with the other "downtrodden masses of India," including Scheduled Tribes and other Backward Classes' (Jaffrelot 2003, p.106-7).

7. Internal students were students who had already joined AMU, either at high school or college level.

8. To increase internal quotas was nothing revolutionary. In 1961, the Chatterji Committee, appointed by the government, had already recommended similar measures to ensure that "the bulk of the overall student population of the University should come from the Muslim community...without fixation of any communal quotas" (AMU 1961, p.140).

9. For the Chatterji Committee, communal quotas were "open to grave objection for it would have been contrary to the liberal ideals which must inspire a temple of learning such as a university." Like the University Education Commission (1948), it endorsed the idea that these quotas represented a "danger of disunion" for the country, which ran counter to universities' role to promote national unity (AMU 1961, p.114-5).

10. In 1958, for instance, the authorities of Benaras Hindu University closed the university following demonstrations and fights between what Altbach (1968) describes as "warring factions." In 1963, students at Allahabad University further used physical threat to force the Vice-Chancellor to re-admit some students (Di Bona 1969).

11. M.C. Chagla to Syed Mahmud. May 20, 1965 in NMML.

12. For instance, Basheer Ahmed Sayeed, member of the University Court, was arrested. He was accused of being one of the main architects of the incident (Khalilullah to M.C. Chagla. August 13, 1965 in NMML, 80). In his letter to Chagla, dated August 17, 1965, Basheer Ahmed Sayeed denied these charges and argued that he had tried to appease the students. According to him, students affiliated with the Jan Sangh, the Jamiat and with communists played the leading role in the agitation against the Vice-Chancellor (NMML, 80).

13. "Aligarh boys' plea for pardon." 1965. Patriot, August 7 in NMML.

14. "Vice-Chancellor's address to Staff Association," August 29, 1965 in Jung.

15. "Presidential Address at the All India Muslim Convention," June 10,1961, in Mahmud.

16. Jamiat Ulama, a religious organization which was established in 1919 , played a key role in the anti-colonial protests during the Khilafat movement, side by side with Congress. In 1947, a majority - not all - of its members opposed partition and the Muslim League, hence its "nationalist" tag. After independence, Congress maintained close ties with the organisation, which they regarded as a representative of Muslims' voices in India.

17. Jamaat-e-Islami was founded in 1941 by Maulana Maududi to transform post-colonial India into an Islamic state. After partition, the Islamist organization split into two Pakistani and Indian branches. The latter one, Jamaat-e-Islami-e-Hind, progressively gave up its isolationist strategy to join democratic politics.

18. 1965. Dawat, July 24, p.3, in NMML. 
19. "Convention leader pleads for Muslim management." 1965. Hindustan Times, August 4; "Aligarh old boys to have panel for 'peaceful action'." 1965. Hindustan Times, August 9, p.1; 1965. Dawat, July 20, in NMML.

20. In M.C. Chagla's papers on the AMU campaign, we can find press clippings from the Urdu press in Delhi (Havat, a communist weekly, Al Jamiat and Dawat, published respectively by the Jamiat Ulama and the Jamaat-e-Islami, Pratap, a pro Jan Sangh newspaper, Savera and Daur-eJadeed), from Lucknow (Qaumi Awaz), Kanpur (Siasat), Ptna (Sangam, Sada-e-Aam), but also from Hyderabad (Rahnuma-e-Deccan), Calcutta (Azad Hind, Rozana Hind), Bombay (Hindustan, Inquilab) and Calicut (Chandrika). In addition, one finds press clippings from the English press based in Delhi (Hindustan Times, Patriot, Hindustan Standard, Link, Indian Express) and Bombay (Times of India, Blitz).

21. “Aligarh Old Boys to Have Panel for 'Peaceful Action."' 1965. Hindustan Times, August, 9 in NMML.

22. Radiance. 1965. June 20, p.4, cited in Wright 1966a.

23. In an article entitled "Running of Aligarh Varsity Exclusively by Muslims Demanded," a journalist shows the identity of demands between Majlis's memorandum and a resolution adopted by Jamaat-e-Islami (1965. Times of India, July 11 in NMML).

24. Some students, teachers, and alumni distanced themselves from the AMU campaign. During the Lucknow Convention, several alumni denounced the attempts of Jamaat-i-Islami to take over "their" convention and to impose a "communal" line upon the movement. Some alumni directly challenged Jamaat's main demands. For instance, S.M. Tonki, an Old Boy of Gandhian persuasion, tried in vain to amend the resolution that demanded an exclusively Muslim control of the University. Together with other Old Boys, he signed a statement of dissent denouncing the "unfortunate alliance" of some veterans of the nationalist movement (they were referring here to Syed Mahmud) with the "reactionary, narrow-minded and sectarian elements" of the Jamaate-Islami. "Threats on Aligarh." 1965. Patriot, August 9 in NMML.

25. Akhtarul Wasey recalls that the University was closed several times in 1972-73 due to students' mobilization against the "Black Act." He himself was arrested, along with a few politicians, like A.J. Faridi, who supported the protests (A. Wasey, personal communication, November 7, 2013). See also press reports such as Wasey 1972 and Times of India 1972b.

26. See the regular articles published in Times of India and Radiance during that period.

27. Nigam (2006, p.320-3) adopts here Partha Chatterjee's famous distinction between "civil" and "political" society.

28. This was the name of AMU alumni's association.

29. This is what Salman Khurshid suggests (2015, p.170-1).

30. See also the joint statement published in November 1978 by a group of students and teachers to support Janata Party's "secular and democratic forces" against Indira Gandhi's "authoritarianism and fascism" (Times of India 1978a).

31. Patrick Clibbens points out that the recruitment strategies of left and right-wing opposition parties relied in large measure on "channeling the enthusiasms of the young," particularly of the "burgeoning" urban youth, more inclined towards "radical" ideas (2014, p.194-5).

32. On the AIMPLB, see Jones 2010. On the BMAC, see Ahmed 2014, p.229-30.

33. On the Muslim League in Kerala, see Wright 1966b. On the Majlis-i-Ittehadul-Muslimeen in Hyderabad, see Alam 1993.

34. Cyclostyled document dated 4 July 1972 distributed by Dr. A.J. Faridi. Excerpts reproduced in Noorani 2003, p.360-1.

35. For Ahmad, the formation of SIMI epitomized the emergence of a new "Islamist class," ready to challenge the authority of elders (2010). For a critique of Muslim minority politics by a SIMI supporter, see Ali 1982. On the Pasmanda movement as a call to the "democratization" of Indian Muslims, see for instance Alam 2003. 


\section{ABSTRACTS}

This article focuses on the campaign for AMU's minority status (1965-1981), at the intersection of student politics and Muslim politics. What started in 1965 as an internal university dispute on student quotas soon transformed into a central Muslim issue. The campaign crystallized mounting resentment against the government and provided a common platform to heterogeneous forces-students, teachers, as well as Muslim organizations of different shades and hues-who all claimed to serve Muslim interests. This campaign thus played a key role in the reconfiguration of Muslim politics in the 1960s. It contributed to the re-emergence of the demand for Muslim minority rights, largely delegitimized after partition. It provided a platform for an increasingly assertive Muslim leadership which claimed to represent the Muslim community. Finally, it constituted a laboratory for issue-based coalitions, which, in the absence of a strong Muslim political party, became a dominant feature of Muslim politics, especially in North India. These changes must be read in the wider context of the post-Nehruvian period. The campaign participated in the emergence of counter-narratives, which questioned Congress's "hegemonic" discourse on secular nationalism. Through student mobilization and issue-based coalitions, it also facilitated the emergence of contentious voices outside party structures. As such, the campaign participated in the larger pluralization of Indian politics, marked by the erosion of Congress's dominance, much before the post-Emergency crisis.

\section{INDEX}

Keywords: Muslims, minority rights, student politics, post-Nehruvian politics, Aligarh Muslim University.

\section{AUTHOR}

\section{LAURENCE GAUTIER}

Assistant Professor at the Jindal School of Liberal Arts, O.P. Jindal Global University, as well as Associate Researcher at the Centre de Sciences Humaines (Delhi). She completed her PhD thesis on "The role of Muslim universities in the redefinition of Indian Muslim Universities after partition (1947-1990s)" at the University of Cambridge (2016). 